\title{
Crisis, Institutional Quality and Economic Growth*
}

\author{
Hasan Vergil ** \\ Istanbul University
}

\author{
Erdoğan Teyyare*** \\ Abant İzet Baysal University
}

\begin{abstract}
Even though there is an agreement on the relationship between institutional quality and economic growth, the re-designing of institutions due to balance of payments and debt crises in some countries in the last 30 years has brought about a discussion of effects of crises on economic growth through changes in institutional quality. This study investigates whether economic crises have an effect on economic growth through changes in institutional quality by employing the Mankiw, Romer and Weil model. Employing panel data methodologies for Argentina, Mexico, Brazil, Thailand, Malaysia, Philippines, Indonesia, South Korea and Turkey, this study finds that changes due to economic crisis in bureaucratic quality, socioeconomic conditions, investment profile, religious tensions and democratic accountability amount to significant variables and, except for religious tensions, they have positive effects on economic growth. Thus, economic crises do change the level of institutional quality and this change, in turn, positively affects economic growth.
\end{abstract}

Keywords: economic crises, institutional quality, economic growth.

JEL Classifications: O43, O17, 047

\section{Kriz, Kurumsal Kalite ve Ekonomik Büyüme}

\section{Özet}

Kurumsal kalite ve ekonomik büyüme ilişkisi konusunda uzlaşma olmasına rağmen, son 30 yılda meydana gelen ekonomik krizler, ülkelerin kurumlarının yeniden dizaynı ile sonuçlanmıştır. Bu çalışmada krizlerin, kurumsal kalite aracılığıyla ülkelerin iktisadi büyümeleri üzerinde etkili olup olmadığı Mankiw, Romer ve Weil (MRW) büyüme modeli ile incelenmiştir. Panel veri tahmin yöntemi kullanılarak araştırılan çalışmada, Arjantin, Meksika ve Brezilya, Tayland, Malezya, Filipinler, Endonezya, Güney Kore ve Türkiye'nin hukuk ve düzen, dinsel çatışmalar, politikada askeri müdahale düzeyi, demokratik katılım düzeyi, içsel ve dışsal çatışmalar değişkenlerinin iktisadi büyümeyi

* This study is based on the Ph.D. dissertation thesis, Crisis, Institutional Quality and Economic Growth, completed in Bülent Ecevit University, Turkey in 2013.

** Hasan Vergil is a Professor in the Department of Economics at Istanbul University, Merkez Kampüs, 34452, Beyazit, İstanbul, Turkey. E-mail: hasan.vergil@istanbul.edu.tr

*** Erdoğan Teyyare is an Assistant Professor in the Department of Finance at Abant Izzet Baysal University, Gölköy Yerleşkesi, 14300, Bolu, Turkey. E-mail:erdoganteyyare@ibu.edu.tr 
pozitif yönde etkileyen önemli kurumsal değişkenler olduğu sonucuna varılmıştır. Ayrıca kurumsal kalite göstergeleri krizin etkisi ile birlikte değerlendirildiğinde; iktisadi büyüme düzeyini pozitif yönde etkileyen kurumsal değişkenlerin; bürokratik kalite, sosyoekonomik koşullar, yatırım profili ve demokratik katılım olduğu tahmin edilmiştir. Sonuç olarak; krizler, kurumsal kalite düzeyini değiştirmektedir ve bu değişim iktisadi büyümeyi pozitif yönde etkilemektedir.

Anahtar Kelimeler: ekonomik kriz, kurumsal kalite, ekonomik büyüme. JEL Sinıflandırmasi: O43, O17, 047

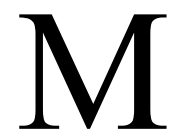

any factors might cause a fragile and unstable economy. Changes in political, economic, technological and ecological conditions might cause economic crises. Many studies in the literature try to explain the reasons for economic crises by bringing up different factors and developing theoretical and empirical models. Recently, some of the studies have aimed to explain causes, intensification and prevention of economic crises as a result of institutional factors rather than economic factors.

The starting point of some studies that aim to explain the relationship between crises and institutions has been that weak institutions lead to uncertain economic environments, doing risky business and the wrong allocation of resources. In addition, weak institutions support economic crises by preventing solutions for economic problems (Shimpalee and Breuer, 2007: 275). Some authors point to weak institutions, or low institutional quality, as one of the reasons for serious economic crises (Du, 2010: 174). The Washington Consensus puts emphasis on different institutional factors including inadequate implementation of property rights and corruption as the primary causes of poor macroeconomic performance and economic fluctuations (Acemoğlu et.al., 2003: 50).

Previous studies that attempted to find a link between institutions and economic crises focused on different aspects of the relationship. For example, weak institutions lead to economic crises because weak institutions provide opportunity for abuse during implementation of agreements (Rajan and Zingales, 1998). In order to examine the relationship between weak institutions and economic crises, Johnson (2002) employs rule of law, judicial efficiency and corruption variables, Block (2002) employs stability, soundness and power of governments variables, Ghosh and Ghosh (2002) employ good governance, rule of law, rights of creditors and rights of partnership variables, and Mulder at.al. (2002) use legitimate system of government, implementation of contracts and accounting standards variables. Alesina and Wagner (2003) and Calvo and Mishkin (2003) associate crises with the affiliation between institutional quality and exchange rate adjustments. Alesina and Wagner (2003) conclude that it is quite difficult to keep exchange rate in a certain bandwidth in countries with low institutional quality in economic, social and political areas. Similarly, Calvo and Mishkin (2003) argued that soundness of fundamental institutions associated with financial stability and price stability are more important than exchange rate regimes in order to achieve macroeconomic stability and prevent economic crises. 
Acemoğlu et.al. (2003) argue that weak institutions lead to economic instability and bad macroeconomic policies. Macroeconomic fluctuations, lack of property rights for the protection of investors, corruption and high level political instability are due to a weak institutional structure of an economy. In this regard, the deterioration in macroeconomic policies combined with the weakness of the institutional structure causes instability. Shimpalee and Breuer (2006) stress that both institutional and economic factors significantly affect the likelihood of crises and weak institutions lead to much bigger losses in crisis environments. According to them, in environments with corruption, weak government stability, lack of law and social order, and fixed exchange rate regimes, the probability of crisis emerging greatly increases. In addition, albeit not as strongly as the above variables, low bureaucratic quality, ethnic tensions and the presence of external and internal conflicts are included as key factors that trigger a crisis. In economies with weak institutions, the possibility of having unstable market expectations might increase and speculative capital outflows which could lead to crisis occur more likely because of the uncertain economic environment. On the other hand, in economies with more solid foundations in terms of institutions, those institutions contribute to the economy by stabilizing economic expectations, reducing uncertainty and holding speculative capital outflows at minimum levels.

Generally, the literature suggests that institutions affect crises through two causal mechanisms: First, institutions can lead to economic crises by creating weak economic foundations and can eliminate the formation of economic crises by forming strong economic structure. Second, institutions have information providing features. Institutions can be a tool of predicting market signals for forecasting future economic foundations. Thus, expectations can be shaped through institutions.

The previous literature investigated the relationship between economic crises and institutions by assuming one way of causality from institutions to economic crises. Further progress awaits the empirical identification of reverse causality such that economic crises affect economic growth of countries by affecting the institutional quality level of countries. Our work contributes to the new institutional economics literature by considering the existence and empirical identification of the reverse causality between economic crises and institutions. Because of the rise in frequency, prevalence and intensity of crises since the 1980s, countries faced economic crises and redesigned their institutions. Thus, it would be very interesting to explore whether or not these changes in institutional quality affected the economic growth of the countries. By searching this strand, this study contributes to the literature by adding an effect of economic crises on the discussion of a well agreed relationship between institutional quality and economic growth in the literature.

The second part of this study reviews the literature on institutional quality and economic growth. The third section gives information about countries facing economic crises and changes in their institutional structure. The fourth section is about data and develops the Mankiw, Romer and Weil (1992) type model by adding institutional quality and economic crisis variables. The last section concludes. 


\section{Institutional Quality and Economic Growth}

Institutions are rules, regulations and economic incentives that occur through laws and policies. Countries can stimulate their physical, human and technological investments by way of these rules, regulations and incentives. Institutions differ in respects of chance, geography and cultural factors by being a preference of a society. Regulations and laws are formed as a common preference of people living together instead of individual preferences of people in a society. Members of a society make institutions and reforms by deciding together by which systems they can reach better economic conditions (Acemoğlu; 2009: 110-112).

Theories of economic growth constitute many factors in the process of economic growth. In this context, some non-economic variables as well as economic factors are included into the analyses to explain growth rate differences among countries. Many authors argue that economic performance is largely determined by the incentive structure created by the institutions. Institutions are one of the determining factors in the economy's long-term performance (Olson, 1996: 22; North, 1994: 359-360; Acemoğlu et.al., 2005: 388-389). Institutional structure affects economic growth by reducing transaction costs and easing transformation of production process (Aron, 2000:104). It is mainly accepted in analyses investigating economic growth and institutions that there is a strong correlation between institutional quality and economic growth. (Mauro, 1995; Knack and Keefer, 1995; Hall and Jones, 1999).

In order to investigate the relationship between institutional variables and economic performance, Knack and Keefer (1995) explain the relationship between economic growth and institutional quality using variables that include an efficient judicial system (rule of law), the level of corruption, the bureaucratic quality, security and enforceability of contracts (recognition of contracts by the government) and expropriation risk of assets by the government. According to Knack and Keefer, there is a strong relationship between institutional quality components and economic growth. Institutional factors affect economic growth through investment channels. If private property rights are well protected, entrepreneurs will be more motivated towards goods and capital accumulation. The increases in accumulation of capital will lead to economic growth in the long term. On the other hand, a rise in the expropriation risk of properties will reduce investment level and investments will shift to other less profitable but more secure economic activities such as just retail sales instead of producing. This will lead to an inadequate increase in physical and human capital.

Mauro (1995) argues that by reducing investments, corruption has a negative effect on economic growth. Improvements in bureaucratic quality provide a better investment environment and affect economic growth positively. Similarly, Barro (1996) shows that rule of law variable affects economic growth more compared to other variables. For example, although political freedoms have a limited but positive effect, a moderate democracy level has a negative effect on economic growth. According to Tanzi and Davoodi (1997), a rise in corruption level affects economic growth negatively by stimulating large scale but low productive public investments and damaging existing 
infrastructure quality. Barro and Sala-i Martin (1997: 9-10) find that while increases in the level of rule of law, political rights and civil liberties positively affect economic growth, military coups, civil unrest and war negatively affect economic growth. Grigorian and Martinez (2000) find a strong and positive relationship between economic growth and institutions in the study of developing countries in Asia and Latin America. In addition, they find that institutional quality affects growth not only by way of investment but also through efficient resource allocation channels.

All of these studies emphasize the existence of strong relationships between institutions and economic growth and have an agreement that institutions are one of the fundamental factors determining economic growth. Since economic crises affect institutional structure and quality, this feature of economic crises needs a close scrutiny to detect this indirect relationship.

\section{Cases for Crises and Institutional Changes}

A number of arrangements and reforms are made in the financial and institutional structure of a country in a crisis. These arrangements can bring about changes in institutional structure, and thus, in economic performance of the country. These configurations and reforms can be at the national level as well as at the international level. Configurations and reforms at the international level largely consist of advice and prescriptions offered by international economic institutions such as the International Monetary Fund (IMF) and the International Bank for Reconstruction and Development (IBRD). Reforms and configurations at the national level include macro and micro scale institutional and financial arrangements.

Latin American countries, namely Mexico, Argentina and Brazil, have brought about significant structural and legal changes by implementing reforms and configurations after the crises they experienced. These reforms generally aimed at the creation of fiscal responsibility legislation and the determining expenditure and budget balance targets in accordance with the numerical measurements. The reforms also aimed to increase transparency (Hallerberg and Scartascini, 2011: 2).

Asian countries that suffered economic crises have implemented a number of structural and institutional reforms and policies. Reforms and configurations implemented in Asian countries are generally composed of the IMF-oriented policies. The structural weaknesses in the financial sector were considered to be one of the main causes of the Asian crisis and the discussions were focused on reforms needed in the financial sector. The restructure of the financial sector aimed to minimize government intervention and to ensure the independence of the banking system. Reforms in the financial sector in Asian countries in general have been proposed as joint programs. The structural reforms of these programs include the closure of insolvent financial institutions, restructuring of financial institutions which may continue to exist, closure of weak financial institutions under the supervision of the Central Bank and strengthening financial supervision and regulation. The reforms also include general policies to bring financial institutions up to international standards with the supervision of financial institutions and arrangements 
in the program and the abandonment of the close relationship between government and the business sector. By implementing these reforms and by restructuring certain sectors, the bankruptcy of companies that lost the capacity to repay their debts and reduction of debt are expected. In these crisis-suffering countries, the condition of immediate closing of the banks which are unable to pay their debts was also included in the reforms (Fischer 1998: 167-176; Topall1, 2006: 149-150).

In order to improve management and competitiveness, policies of rearrangement of state-supported monopolies and cartels, strengthening competition law and increase the transparency of economic and financial data have been implemented through structural reforms in Asian countries. In addition, the existing liberalization plans are maintained through international trade reforms to prevent restrictions which cause economic woes in neighboring countries. A number of social sector reforms were made to strengthen and expand the social safety nets. These reforms have aimed to increase income transfers, to limit unemployment through various employment and training programs, to provide ongoing support for low-income earners to reduce the impact of price increases on food, energy and transportation and to achieve necessary health and education services (Lane, 1999: 44-47).

One of the other crisis suffering country is Turkey, which implemented a "Transition to Strong Economy Program" in the aftermath of the crisis in May 2001, to relieve financial and real sectors and to help the economy recover in general. The main objective of the program was to take rapid measures for the banking sector in order to reduce uncertainty in financial markets; to ensure stability in exchange rates and interest rates accordingly; to implement structural reforms to ensure economic efficiency; to use macroeconomic policies effectively in the fight against inflation and to provide a sustainable growth medium. In this context, ensuring a sustainable growing debt burden of the public sector, fiscal policy was tightened further, the Central Bank's impact on short-term interest rates has been increased and an exchange rate system was converted to a floating exchange rate system. The program aimed to resolve the structural problems in the economy and gave priority to the restructuring of the banking sector. In this context, the "Banking Sector Restructuring Program" was implemented. This program is mainly based on restructuring state banks from the financial and operational aspects; resolving urgently the situation of banks in the Savings Deposits Insurance Fund (TMSF); attaining a healthy structure of private banks after the crisis and making necessary legal and institutional arrangements for the banking sector to be more efficient and competitive (Baykal, 2007: 40; BDDK, 2009: 9-23). Another structural reform after the February 2001 crisis has been the replacement of the Central Bank Law. Legal changes that occurred in May 2001 included a ban on lending to the public starting November 2001, an assurance of administrative independence of the Central Bank, an official statement that price stability is the main objective of the Central Bank. After these legislative amendments, the Central Bank's main priorities have been to ensure stability in financial markets and to prevent providing an outstanding amount of liquidity to the market which leads to a jump in inflation (BDDK, 2009: 26). 
Parallel to international applications, in order to have a well-functioning market economy in Turkey, the Capital Markets Board, the Banking Regulation and Supervision Agency (BDDK), the Competition Authority, the Telecommunications Authority, the Energy Market Regulatory Authority, the Tobacco Board, and the Public Procurement Board were established. These boards have helped the economy management steer free from politics, have contributed to the improvement of public expenditure management and a more effective government structure. In order to increase institutional capacity in the period that followed the crisis, the BDDK's control area was expanded, the organizational structure was revised, a strategic planning approach was adopted, the editing process was made more participatory and transparent and the audit system approach was strengthened through new methods and applications (BDDK, 2009: 1-43).

Stated these changes in the institutions of crisis suffered countries in the sample, it would be helpful to show growth performance of these countries before and after the crisis. Table 1 shows average growth rates of countries before and after 10 years of economic crisis they suffered. The ten year time period is chosen to see regular growth performance of countries. Table 1 shows that growth rates of Mexico, Brazil, Argentina, Philippines and Turkey increased as an average after 10 years of the crisis compared to average growth rates of 10 years before the crisis. All of the Latin American countries, one Asian country, Philippines, and Turkey raised their growth rates as an average after the crisis hit. All of the countries with decreasing average growth rates after the crisis are Asian countries.

Table 1

Average Growth Rates of Countries in the Sample

\begin{tabular}{l|l|l|l|l}
\hline Country & Crisis Year & Before Crisis & After Crisis & Result \\
\hline Mexico & 1995 & 2.79 & 3.38 & increased \\
\hline Brazil & 1998 & 1.99 & 3.38 & increased \\
\hline Argentina & 2002 & 2.97 & 6.52 & increased \\
\hline Indonesia & 1998 & 7.61 & 4.72 & decreased \\
\hline Malaysia & 1998 & 9.27 & 5.55 & decreased \\
\hline Philippines & 1998 & 3.80 & 4.65 & increased \\
\hline Thailand & 1998 & 8.43 & 4.74 & decreased \\
\hline Korea, Rep. & 1998 & 8.02 & 5.67 & decreased \\
\hline Turkey & 2001 & 3.73 & 5.45 & increased \\
\hline
\end{tabular}

Source: Authors' calculations from World Development Indicators.

The crisis year is the deepest crisis time of countries. 
Asian countries had the high degree of openness to and integration with world markets and very high growth rates in the 1990s. Their remarkable growth rates before the crisis relied heavily on substantial capital inflows from the advanced world although they began running large current account deficits as a share of GDP during these years. After the crisis hit Asian countries, they implemented a number of structural and institutional reforms and their growth rates declined to still very high but sustainable rates. These results suggest that countries in the sample underwent structural changes after the crisis and these changes allowed them to reach higher or sustainable growth rates compared to rates before the crisis.

\section{Data and the Model}

In this study, the augmented Solow Model of Mankiw, Romer and Weil (1992) is used to quantify the effect of institutional quality change due to economic crises on economic growth of countries. Mankiw Romer and Weil (1992) added human capital variable to the basic Solow Model in order to explain cross-country income differences. In their model, total savings in an economy decomposed as a human capital stock and physical capital stock. If $s_{k}$ shows a share of physical capital stock in national income and $s_{h}$ shows a share of human capital stock in national income, their model can be expressed as:

$\ln \left[\frac{Y(t)}{L(t)}\right]=\ln A(0)+g t-\frac{\alpha+\beta}{1-\alpha-\beta} \ln (n+g+\delta)+\frac{\alpha}{1-\alpha-\beta} \ln \left(s_{k}\right)+\frac{\beta}{1-\alpha-\beta} \ln \left(s_{h}\right)$

Where $n$ denotes population growth rate, $g$ denotes technology growth rate and $\delta$ denotes depreciation rate. In addition, $0 \leq \alpha, \beta \leq 1$ and $Y / L$ is income per worker. $A(0)$ term reflects not only technology but also reflects institutions, climate, resource endowments, etc. So it may be different across countries:

$$
\ln A(0)=a+\varepsilon
$$

Assume $g$ and $\delta$ are constant across countries, the model can be reduced to:

$\ln \left[\frac{Y}{L}\right]_{i t}=\lambda_{0}+\lambda_{1} \ln L_{i t}+\lambda_{2} \ln K_{i t}+\lambda_{3} \ln H_{i t}+\varepsilon_{i t}$

where

$$
\begin{aligned}
& \lambda_{0}=a+g t, \lambda_{1}=\frac{\alpha+\beta}{1-\alpha-\beta}, \ln (L)=\ln (n+g+\delta), \lambda_{2}=\frac{\alpha}{1-\alpha-\beta}, \ln (K)=\ln \left(s_{k}\right) \\
& \lambda_{3}=\frac{\beta}{1-\alpha-\beta}, \ln (H)=\ln \left(s_{h}\right)
\end{aligned}
$$

and $\varepsilon$ is an idiosyncratic error term. We theoretically expect that $\lambda_{1}<0, \lambda_{2}>0$ and $\lambda_{3}>0$.

Since we are going to investigate the effect of economic crisis on economic growth 
through its changes on institutional quality, we added a dummy variable to be a proxy for economic crisis into the model. The dummy variables take different values associated with countries' crisis time. Thus, based on the deepest crisis time of countries, the dummy variable takes a value of 1 when crisis started and 0 before the crisis years. The starting year of crisis is 1994 for Mexico, 1999 for Brazil, 2001 for Argentina, 1997 for all Asian countries and 2001 for Turkey. In addition, institutional quality variables are added to the model to investigate the effect of institutional quality on economic growth. Finally, the multiplication of dummy variables with institutional quality variables are added to search the effect on institutional quality changes due to economic crisis on economic growth. Thus, the model is now in the form of;

$\ln P G D P_{i t}=\lambda_{0 i}+\lambda_{1} \ln K_{i t}+\lambda_{2} \ln L_{i t}+\alpha_{3} \ln H_{i t}+\lambda_{4} D_{i t}+\lambda_{5} I Q_{i t}+\lambda_{6} D_{i t} * I Q_{i t}+\varepsilon_{i t}$

where, PGDP is a per capita GDP, D is a dummy variable and IQ shows an institutional quality variable. This model will be estimated using 12 different institutional quality variables.

Panel data methodology is used to estimate the model for the countries Mexico, Argentina, Brazil, Tailand, Indonesia, Malaysia, Philippines, South Korea and Turkey for the period 1984-2010. Data for the variables for the basic Mankiw, Romer, Weil model have been obtained from World Bank World Development Indicators (WDI). All variables are in USD and converted to real terms. The dependent variable $(P G D P)$ is a per capita GDP of the countries in the sample, physical investment rate $(K)$ is defined as [real investment /real GDP], population growth rate $(L)$ is calculated as the sum of [population growth rate of countries $(n)$, technology growth rate $(g)$ and physical depreciation rate $(\delta),(n+g+\delta)$ and human capital variable $(H)$ is defined as a ratio of number students enrolled in secondary school to a number of population above fifteen years. As in the Mankiw, Romer, Weil paper, $(g+\delta)$ is taken as 0.05 constant for all countries.

Since human capital variable is not readily available in WDI for all countries and time periods, "A Database of Educational Attainment in the World" by Barro and Lee (2010) is used. Since Barro and Lee's data is published quinquennially, these data have been converted to yearly data by considering ratios of changes between each five years, assuming that changes constantly took place in each five year time period.

There are many indices to indicate institutional quality. This study uses 12 components of the Political Risk Ratings as published by the International Country Risk Guide (ICRG) since 1984. The reason of choosing these indices is that, as emphasized by Alesina and Weder (1999), these indices are mostly used in academic research because of the longest running data set covering the largest countries and because they have sub-components.

The following Political Risk Components are used to produce the political risk rating of countries and used in this study as indicators of institutional quality:

- Government Stability

- Socioeconomic Conditions

- Investment Profile 
- Internal Conflict

- External Conflict

- Corruption

- Military in Politics

- Religious Tensions

- Law and Order

- Ethnic Tensions

- Democratic Accountability

- Bureaucracy Quality

The model (5) is modified by adding each political risk component into the model as an indicator of institutional quality and it is shown below together with basic Mankiw, Romer, Weil model.

$\ln P G D P_{i t}=\lambda_{0 i}+\lambda_{1} \ln K_{i t}+\lambda_{2} \ln L_{i t}+\lambda_{3} \ln H_{i t}+\varepsilon_{i t}$

$\ln P G D P_{i t}=\lambda_{0 i}+\lambda_{1} \ln K_{i t}+\lambda_{2} \ln L_{i t}+\lambda_{3} \ln H_{i t}+\lambda_{4} D_{i t}+\lambda_{5} G S_{i t}+\lambda_{6} D_{i t} * G S_{i t}+\varepsilon_{i t}$

$\ln P G D P_{i t}=\lambda_{0 i}+\lambda_{1} \ln K_{i t}+\lambda_{2} \ln L_{i t}+\lambda_{3} \ln H_{i t}+\lambda_{4} D_{i t}+\lambda_{5} S C_{i t}+\lambda_{6} D_{i t} * S C_{i t}+\varepsilon_{i t}$

$\ln P G D P_{i t}=\lambda_{0 i}+\lambda_{1} \ln K_{i t}+\lambda_{2} \ln L_{i t}+\lambda_{3} \ln H_{i t}+\alpha_{4} D_{i t}+\lambda_{5} I P_{i t}+\lambda_{6} D_{i t} * I P_{i t}+\varepsilon_{i t}$

$\ln P G D P_{i t}=\lambda_{0 i}+\lambda_{1} \ln K_{i t}+\lambda_{2} \ln L_{i t}+\lambda_{3} \ln H_{i t}+\lambda_{4} D_{i t}+\lambda_{5} I C_{i t}+\lambda_{6} D_{i t} * I C_{i t}+\varepsilon_{i t}$

$\ln P G D P_{i t}=\lambda_{0 i}+\lambda_{1} \ln K_{i t}+\lambda_{2} \ln L_{i t}+\lambda_{3} \ln H_{i t}+\lambda_{4} D_{i t}+\lambda_{5} E C_{i t}+\lambda_{6} D_{i t} * E C_{i t}+\varepsilon_{i t}$

$\ln P G D P_{i t}=\lambda_{0 i}+\lambda_{1} \ln K_{i t}+\lambda_{2} \ln L_{i t}+\lambda_{3} \ln H_{i t}+\lambda_{4} D_{i t}+\lambda_{5} C R_{i t}+\lambda_{6} D_{i t} * C R_{i t}+\varepsilon_{i t}$

$\ln P G D P_{i t}=\lambda_{0 i}+\lambda_{1} \ln K_{i t}+\lambda_{2} \ln L_{i t}+\lambda_{3} \ln H_{i t}+\lambda_{4} D_{i t}+\lambda_{5} M P_{i t}+\lambda_{6} D_{i t} * M P_{i t}+\varepsilon_{i t}$

$\ln P G D P_{i t}=\lambda_{0 i}+\lambda_{1} \ln K_{i t}+\lambda_{2} \ln L_{i t}+\lambda_{3} \ln H_{i t}+\lambda_{4} D_{i t}+\lambda_{5} R T_{i t}+\lambda_{6} D_{i t} * R T_{i t}+\varepsilon_{i t}$

$\ln P G D P_{i t}=\lambda_{0 i}+\lambda_{1} \ln K_{i t}+\lambda_{2} \ln L_{i t}+\lambda_{3} \ln H_{i t}+\lambda_{4} D_{i t}+\lambda_{5} L O_{i t}+\lambda_{6} D_{i t} * L O_{i t}+\varepsilon_{i t}$

$\ln P G D P_{i t}=\lambda_{0 i}+\lambda_{1} \ln K_{i t}+\lambda_{2} \ln L_{i t}+\lambda_{3} \ln H_{i t}+\lambda_{4} D_{i t}+\lambda_{5} E T_{i t}+\lambda_{6} D_{i t} * E T_{i t}+\varepsilon_{i t}$

$\ln P G D P_{i t}=\lambda_{0 i}+\lambda_{1} \ln K_{i t}+\lambda_{2} \ln L_{i t}+\lambda_{3} \ln H_{i t}+\lambda_{4} D_{i t}+\alpha_{5} D A_{i t}+\lambda_{6} D_{i t} * D A_{i t}+\varepsilon_{i t}$

$\ln P G D P_{i t}=\lambda_{0 i}+\lambda_{1} \ln K_{i t}+\lambda_{2} \ln L_{i t}+\lambda_{3} \ln H_{i t}+\alpha_{4} D_{i t}+\lambda_{5} B Q_{i t}+\lambda_{6} D_{i t} * B Q_{i t}+\varepsilon_{i t}$

where abbreviations for political risk components are such that GS: Government Stability, SC: Socioeconomic Conditions, IP: Investment Profile, IC: Internal Conflict, EC: External Conflict, CR: Corruption, MP: Military in Politics, RT: Religious Tensions, LO: Law and Order, ET: Ethnic Tensions, DA: Democratic Accountability, BQ: Bureaucracy Quality.

Among these models, while the model (6) is a basic Mankiw, Romer, Weil model, the other models include one of the political risk components as an institutional qual- 
ity indicator. In this study, the effect of economic crises on economic growth through institutional quality changes is investigated using yearly data of 9 countries with panel data methodologies over the period 1984-2010.

There are four estimators of panel data models, namely, pooled OLS (POLS), Fixed Effects estimator (FE), first difference estimator (FD) and random effects estimator (RE). Choosing the correct estimator depends on justification of certain model assumptions. The first test to choose the correct model is to search whether time invariant unobservable effects are uncorrelated with the explanatory variables. This test is conducted by a Hausman test comparing fixed effects and random effects estimators. The second test is whether the intercept might differ across subjects. This test is conducted with the standard $\mathrm{F}$ test by imposing a common intercept for all countries in a restricted model. ${ }^{[1]}$ Table 2 shows the results of F-test and Hausman test for the model selection.

Table 2

\section{Results of F Test and Hausman Test}

\begin{tabular}{|c|c|c|c|c|c|}
\hline \multirow{3}{*}{ Models } & \multicolumn{2}{|l|}{ F Test } & \multicolumn{2}{|c|}{ Hausman Test } & \multirow{3}{*}{ Model Selection } \\
\hline & \multicolumn{2}{|c|}{$\begin{array}{l}\text { H0:The model has a common } \\
\text { intercept }\end{array}$} & \multicolumn{2}{|c|}{$\begin{array}{l}\text { H0:Time invariant effect } \\
\text { is uncorrelated with the } \\
\text { explanatory variables }\end{array}$} & \\
\hline & F-Statistic & $\mathrm{p}$-value & $\chi^{2 \text {-statistic }}$ & p-value & \\
\hline Equation 6 & 97.0034 & {$[0.0000]$} & 2.0323 & {$[0.5657]$} & $\mathrm{RE}$ \\
\hline Equation 7 & 97.4683 & {$[0.0000]$} & 23.0951 & {$[0.0008]$} & $\mathrm{FE}$ \\
\hline Equation 8 & 96.8093 & {$[0.0000]$} & 33.2712 & {$[0.0000]$} & FE \\
\hline Equation 9 & 107.5118 & {$[0.0000]$} & 7.6317 & {$[0.2663]$} & $\mathrm{RE}$ \\
\hline Equation 10 & 74.4953 & {$[0.0000]$} & 7.8226 & {$[0.2514]$} & $\mathrm{RE}$ \\
\hline Equation 11 & 101.3221 & {$[0.0000]$} & 1.8878 & [0.9297] & $\mathrm{RE}$ \\
\hline Equation 12 & 64.2091 & {$[0.0000]$} & 8.6842 & [0.1921] & $\mathrm{RE}$ \\
\hline Equation 13 & 56.5649 & {$[0.0000]$} & 39.9095 & {$[0.0000]$} & FE \\
\hline Equation 14 & 81.6536 & {$[0.0000]$} & 25.9899 & {$[0.0002]$} & FE \\
\hline Equation 15 & 83.6156 & {$[0.0000]$} & 18.7504 & {$[0.0046]$} & FE \\
\hline Equation 16 & 100.5101 & {$[0.0000]$} & 1.8271 & [0.9349] & $\mathrm{RE}$ \\
\hline Equation 17 & 95.1415 & {$[0.0000]$} & 1.8143 & {$[0.9360]$} & $\mathrm{RE}$ \\
\hline Equation 18 & 93.4923 & {$[0.0000]$} & 2.6413 & {$[0.8523]$} & RE \\
\hline
\end{tabular}

[1] In order to save a space, the details are not given for the models and these tests. The reader can refer textbooks such as Wooldridge (2010) and Baltagi (2013). 
These statistics reveal that while the null hypothesis of all differential intercepts equal to zero is rejected at $1 \%$ significance level for all models, the null hypothesis of Hausman test is rejected for Equation 7, Equation 8, Equation 13, Equation 14 and Equation 15. Thus, the Fixed Effects estimator will be used to estimate these equations while the Random Effects estimator will be used to estimate the rest of them. The next step is to estimate the models with selected estimators and Table 3, Table 4 and Table 5 show parameter estimations.

The results of equation 6 reveal that the coefficients in the basic model are in line with theoretical expectations: while a rise in physical capital and human capital increase economic growth, increase in population growth rate decreases economic growth. The elasticity of economic growth with respect to human capital is higher than the elasticity of economic growth with respect to physical capital.

The rest of the equations are augmented forms of the Equation 6 by adding proxy variables for institutional quality and economic crisis. These models will be evaluated, first, by examining the relationship between institutional quality and economic growth and, second, by examining this relationship with respect to changes in institutional quality due to economic crises.

Table 3

Estimation Results (Equation 6-10)

\begin{tabular}{|c|c|c|c|c|c|}
\hline MODEL & Equation 6 & Equation 7 & Equation 8 & Equation 9 & Equation 10 \\
\hline Variable & $\begin{array}{l}\text { Coefficient } \\
\text { (Probability) }\end{array}$ & $\begin{array}{l}\text { Coefficient } \\
\text { (Probability) }\end{array}$ & $\begin{array}{l}\text { Coefficient } \\
\text { (Probability) }\end{array}$ & \begin{tabular}{|l|} 
Coefficient \\
(Probability)
\end{tabular} & $\begin{array}{l}\text { Coefficient } \\
\text { (Probability) }\end{array}$ \\
\hline K & $\begin{array}{l}0.4434 \\
{[0.000]}\end{array}$ & $\begin{array}{l}0.4805 \\
{[0.010]}\end{array}$ & $\begin{array}{l}0.5288 \\
{[0.004]}\end{array}$ & $\begin{array}{l}0.2818 \\
{[0.000]}\end{array}$ & $\begin{array}{l}0.3797 \\
{[0.000]}\end{array}$ \\
\hline $\mathrm{L}$ & $\begin{array}{l}-0.3758 \\
{[0.000]}\end{array}$ & $\begin{array}{l}-1.1148 \\
{[0.000]}\end{array}$ & $\begin{array}{l}-0.9408 \\
{[0.000]}\end{array}$ & $\begin{array}{l}-0.3797 \\
{[0.000]}\end{array}$ & $\begin{array}{l}-0.4975 \\
{[0.000]}\end{array}$ \\
\hline $\mathrm{H}$ & $\begin{array}{l}0.9051 \\
{[0.000]}\end{array}$ & $\begin{array}{l}0.5873 \\
{[0.005]}\end{array}$ & $\begin{array}{l}0.6338 \\
{[0.004]}\end{array}$ & $\begin{array}{l}0.8793 \\
{[0.000]}\end{array}$ & $\begin{array}{l}0.9592 \\
{[0.000]}\end{array}$ \\
\hline GS & & $\begin{array}{l}-0.0000 \\
{[0.011]}\end{array}$ & & & \\
\hline $\mathrm{D}$ & & $\begin{array}{l}8.8752 \\
{[0.683]}\end{array}$ & & & \\
\hline GS*D & & $\begin{array}{l}-1.0303 \\
{[0.756]}\end{array}$ & & & \\
\hline $\mathrm{SC}$ & & & $\begin{array}{l}1.2555 \\
{[0.407]}\end{array}$ & & \\
\hline $\mathrm{D}$ & & & $\begin{array}{l}38.375 \\
{[0.004]}\end{array}$ & & \\
\hline $\mathrm{SC} * \mathrm{D}$ & & & $\begin{array}{l}10.680 \\
{[0.000]}\end{array}$ & & \\
\hline
\end{tabular}


Table 3 (continued)

\begin{tabular}{|c|c|c|c|c|c|}
\hline MODEL & Equation 6 & Equation 7 & Equation 8 & Equation 9 & Equation 10 \\
\hline Variable & $\begin{array}{l}\text { Coefficient } \\
\text { (Probability) }\end{array}$ & $\begin{array}{l}\text { Coefficient } \\
\text { (Probability) }\end{array}$ & $\begin{array}{l}\text { Coefficient } \\
\text { (Probability) }\end{array}$ & $\begin{array}{l}\text { Coefficient } \\
\text { (Probability) }\end{array}$ & $\begin{array}{l}\text { Coefficient } \\
\text { (Probability) }\end{array}$ \\
\hline IP & & & & $\begin{array}{l}1.6384 \\
{[0.109]} \\
\end{array}$ & \\
\hline D & & & & $\begin{array}{l}-39.652 \\
{[0.000]}\end{array}$ & \\
\hline IP*D & & & & $\begin{array}{l}5.8585 \\
{[0.000]}\end{array}$ & \\
\hline IC & & & & & $\begin{array}{l}2.6350 \\
{[0.012]}\end{array}$ \\
\hline $\mathrm{D}$ & & & & & $\begin{array}{l}-16.731 \\
{[0.230]}\end{array}$ \\
\hline IC*D & & & & & $\begin{array}{l}0.6089 \\
{[0.635]}\end{array}$ \\
\hline $\mathrm{R}^{2}$ & 0.6931 & 0.7086 & 0.7516 & 0.7403 & 0.7180 \\
\hline $\mathrm{F}(6.8)$ & & 61.61 & 63.79 & & \\
\hline $\begin{array}{l}\text { Wald } \\
\text { Chi-Square }\end{array}$ & 211.45 & & & 193.85 & 326.83 \\
\hline $\begin{array}{l}\text { Number of } \\
\text { Obs. }\end{array}$ & 243 & 243 & 243 & 243 & 243 \\
\hline
\end{tabular}

Notes: Heteroscedasticity, autocorrelation and cross-section dependence problems are solved using Parks-Kmenta estimator in Random Effects models and using Driscoll-Kraay estimators in Fixed Effects models. Wald chi-square coefficients test whether coefficients in Random Effects models are simultaneously significant. Coefficients of institutional quality and dummy variables are calculated by the "Kennedy Approach" using the formula $g^{*}=100 * e^{(\widehat{\beta}-V(\widehat{\beta}) / 2}-1$ (Kennedy, 1981:801).

In all equations, 7 out of 12 institutional quality indicators (Government Stability, Internal Conflict, External Conflict, Military in Politics, Law and Order, Religious Tensions and Democratic Accountability) are statistically significant. The remaining 5 indicators (Socioeconomic Conditions, Investment Profile, Corruption, Ethnic Tensions and Bureaucracy Quality) are statistically insignificant. The sign of all significant variables, except Government Stability, is positive, implying that there is a positive relationship between institutional quality and economic growth for the period investigated and for the countries in the sample. ${ }^{[2]}$ Among these significant variables, the Law and Order variable has the highest coefficient; 1 unit increase in the Law and Order variable increases economic growth $11.43 \%$. This variable is a proxy for the strength and objectivity of a legal system and for the extent compliance with the law.

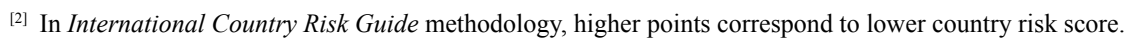


Table 4

Estimation Results (Equation 11-15)

\begin{tabular}{|c|c|c|c|c|c|}
\hline MODEL & Equation 11 & Equation 12 & Equation 13 & Equation 14 & Equation 15 \\
\hline Variable & $\begin{array}{l}\begin{array}{l}\text { Coefficient } \\
\text { (Probability) }\end{array} \\
\end{array}$ & \begin{tabular}{|l|l}
$\begin{array}{l}\text { Coefficient } \\
\text { (Probability) }\end{array}$ \\
\end{tabular} & $\begin{array}{l}\begin{array}{l}\text { Coefficient } \\
\text { (Probability) }\end{array} \\
\end{array}$ & \begin{tabular}{|l} 
Coefficient \\
(Probability)
\end{tabular} & $\begin{array}{l}\text { Coefficient } \\
\text { (Probability) }\end{array}$ \\
\hline K & $\begin{array}{l}0.4264 \\
{[0.000]}\end{array}$ & $\begin{array}{l}0.3368 \\
{[0.000]}\end{array}$ & $\begin{array}{l}0.4797 \\
{[0.017]}\end{array}$ & $\begin{array}{l}0.5584 \\
{[0.000]}\end{array}$ & $\begin{array}{l}0.4189 \\
{[0.025]}\end{array}$ \\
\hline $\mathrm{L}$ & $\begin{array}{l}-0.3890 \\
{[0.000]}\end{array}$ & \begin{tabular}{|l|}
-0.5495 \\
{$[0.000]$} \\
\end{tabular} & $\begin{array}{l}-1.1329 \\
{[0.000]} \\
\end{array}$ & \begin{tabular}{|l|}
-1.1358 \\
{$[0.000]$} \\
\end{tabular} & $\begin{array}{l}-1.0748 \\
{[0.001]} \\
\end{array}$ \\
\hline $\mathrm{H}$ & $\begin{array}{l}0.9435 \\
{[0.000]}\end{array}$ & \begin{tabular}{|l|}
0.9882 \\
{$[0.000]$}
\end{tabular} & $\begin{array}{l}0.6425 \\
{[0.005]}\end{array}$ & \begin{tabular}{|l|}
0.6127 \\
{$[0.000]$}
\end{tabular} & $\begin{array}{l}0.6784 \\
{[0.002]}\end{array}$ \\
\hline $\mathrm{EC}$ & $\begin{array}{l}2.1739 \\
{[0.010]}\end{array}$ & & & & \\
\hline $\mathrm{D}$ & $\begin{array}{l}5.0075 \\
{[0.729]} \\
\end{array}$ & & & & \\
\hline $\mathrm{EC} * \mathrm{D}$ & $\begin{array}{l}-1.6850 \\
{[0.316]}\end{array}$ & & & & \\
\hline CR & & \begin{tabular}{|l|}
2.7004 \\
{$[0.225]$} \\
\end{tabular} & & & \\
\hline $\mathrm{D}$ & & \begin{tabular}{|l|}
-11.383 \\
{$[0.212]$}
\end{tabular} & & & \\
\hline$C R^{*} \mathrm{D}$ & & $\begin{array}{l}1.4496 \\
{[0.597]}\end{array}$ & & & \\
\hline MP & & & $\begin{array}{l}5.7109 \\
{[0.042]}\end{array}$ & & \\
\hline $\mathrm{D}$ & & & $\begin{array}{l}19.333 \\
{[0.394]}\end{array}$ & & \\
\hline $\mathrm{MP} * \mathrm{D}$ & & & $\begin{array}{l}-4.0784 \\
{[0.404]}\end{array}$ & & \\
\hline RT & & & & \begin{tabular}{|l|}
9.5638 \\
{$[0.001]$}
\end{tabular} & \\
\hline $\mathrm{D}$ & & & & $\begin{array}{l}90.940 \\
{[0.000]}\end{array}$ & \\
\hline $\mathrm{RT} * \mathrm{D}$ & & & & $\begin{array}{l}-12.243 \\
{[0.000]}\end{array}$ & \\
\hline LO & & & & & $\begin{array}{l}11.428 \\
{[0.000]}\end{array}$ \\
\hline $\mathrm{D}$ & & & & & $\begin{array}{l}-6.3568 \\
{[0.650]}\end{array}$ \\
\hline $\mathrm{LO}^{*} \mathrm{D}$ & & & & & $\begin{array}{l}4.7158 \\
{[0.195]}\end{array}$ \\
\hline $\mathrm{R}^{2}$ & 0.7209 & 0.7159 & 0.7054 & 0.7267 & 0.7486 \\
\hline $\mathrm{F}(6.8)$ & & & 54.44 & 79.92 & 51.25 \\
\hline Wald Chi-Square & 306.44 & 346.41 & & & \\
\hline Number of Obs. & 243 & 243 & 243 & 243 & 243 \\
\hline
\end{tabular}

Notes: Heteroscedasticity, autocorrelation and cross-section dependence problems are solved using Parks-Kmenta estimator in Random Effects models and using Driscoll-Kraay estimators in Fixed Effects models. Wald chi-square coefficients test whether coefficients in Random Effects models are simultaneously significant. Coefficients of institutional quality and dummy variables are calculated by the "Kennedy Approach" using the formula (Kennedy, 1981:801). 
The principles of rule of law and the independence of the judiciary must prevail in an effective legal system and the rule of law and the independence of the judiciary are important factors for the security of contracts and property rights, the expropriation of assets, and for settlements of disputes. Thus, there exists a strong relationship between legal infrastructure level and economic growth. Protecting property rights and the security of contracts reduces transaction costs and increases investments while better protection of private property rights encourages entrepreneurs to save and invest more.

Table 5

\section{Estimation Results (Equation 16-18)}

\begin{tabular}{|c|c|c|c|}
\hline MODEL & Equation 16 & Equation 17 & Equation 18 \\
\hline Variable & $\begin{array}{l}\text { Coefficient } \\
\text { (Probability) }\end{array}$ & $\begin{array}{l}\text { Coefficient } \\
\text { (Probability) }\end{array}$ & $\begin{array}{l}\text { Coefficient } \\
\text { (Probability) }\end{array}$ \\
\hline K & $\begin{array}{l}0.4081 \\
{[0.000]}\end{array}$ & $\begin{array}{l}0.3793 \\
{[0.000]}\end{array}$ & $\begin{array}{l}0.3641 \\
{[0.000]}\end{array}$ \\
\hline $\mathrm{L}$ & $\begin{array}{l}-0.4219 \\
{[0.000]}\end{array}$ & $\begin{array}{l}-0.4942 \\
{[0.000]}\end{array}$ & $\begin{array}{l}-0.4621 \\
{[0.000]}\end{array}$ \\
\hline $\mathrm{H}$ & $\begin{array}{l}0.9259 \\
{[0.000]}\end{array}$ & $\begin{array}{l}0.9760 \\
{[0.000]}\end{array}$ & $\begin{array}{l}0.9601 \\
{[0.000]}\end{array}$ \\
\hline ET & $\begin{array}{l}2.3104 \\
{[0.183]}\end{array}$ & & \\
\hline $\mathrm{D}$ & $\begin{array}{l}-18.715 \\
{[0.056]}\end{array}$ & & \\
\hline ET*D & $\begin{array}{l}1.8774 \\
{[0.363]}\end{array}$ & & \\
\hline DA & & $\begin{array}{l}2.6936 \\
{[0.086]}\end{array}$ & \\
\hline $\mathrm{D}$ & & $\begin{array}{l}-28.235 \\
{[0.001]}\end{array}$ & \\
\hline $\mathrm{DA}^{*} \mathrm{D}$ & & $\begin{array}{l}5.0030 \\
{[0.014]}\end{array}$ & \\
\hline BQ & & & $\begin{array}{l}0.0011 \\
{[0.174]}\end{array}$ \\
\hline $\mathrm{D}$ & & & $\begin{array}{l}-38.802 \\
{[0.000]}\end{array}$ \\
\hline$B Q * D$ & & & $\begin{array}{l}16.747 \\
{[0.000]}\end{array}$ \\
\hline $\mathrm{R}^{2}$ & 0.7245 & 0.7295 & 0.6979 \\
\hline Wald Chi-Square & 246.03 & 311.17 & 336.85 \\
\hline Number of Obs. & 243 & 243 & 243 \\
\hline
\end{tabular}

Notes: Heteroscedasticity, autocorrelation and cross-section dependence problems are solved using Parks-Kmenta estimator. Wald chi-square coefficients test whether coefficients in Random Effects models are simultaneously significant. Coefficients of institutional quality and dummy variables are calculated by the "Kennedy Approach" using the formula (Kennedy, 1981:801). 
The other significant institutional variables (Religious Tensions, Military in Politics, Democratic Accountability, Internal Conflict and External Conflict) positively affect economic growth. 1 unit rise in these variables increases economic growth $9.56 \%, 5.71 \%$, $2.69 \%, 2.64 \%$ and $2.17 \%$, respectively. Since Religious Tensions, Military Intervention in politics and Internal and External conflicts create uncertain economic and political environments, these will bring risks for investors. Thus, investments will be less and economic growth will be low.

The result of the higher religious tensions, lower religious conflict levels and the higher economic growth rates is theoretically expected and in line with the conclusions of Montalvo and Reynal-Querol (2002) and Easterly and Levine (1997). Religious conflicts generally appears as a result of the domination of one religious group in a society or government. These kinds of groups might want to exclude other religions in the social or political arena or they may want to establish their religious rules instead of civil law rules. These kinds of religious conflicts might cause an uncertain economic environment, inefficient functioning of government and discourage investments.

The higher Military in Politics variable in the International Country Risk Guide methodology corresponds to less military intervention. This result is theoretically expected and in line with the conclusions of Asteriou and Price (2001), Alesina et.al. (1996) and Sala-i Martin (1997). These studies argue that under military direction, elected governments or policies of elected governments can be overhauled in some countries. The possibility of a military coup at any moment prevents effective functioning of governments and creates risks for foreign investors due to the lack of a safe economic environment. This kind of economic condition causes low economic growth rates due to falling investment rates because of the low expected returns (Asteriou and Price, 2001: 386; Sala-i Martin, 1997: 9-10).

The positive relationship, albeit with weak statistical significance, between Democratic Accountability and economic growth is also theoretically expected. While some studies, for example, Brunetti (1998), point out a weak relationship between economic growth and democracy, some studies, for example, (Knack and Keefer, 1995; Sala-I Martin, 1997; Barro, 1996; Rodrik, 2000), claimed positive relationship and some studies, for example, (Levine and Renelt, 1992; Helliwell, 1996; Dollar and Kraay, 2003), claimed negative relationship between economic growth and democracy. The results of Internal Conflict and External Conflict variables are also consistent with previous literature such as (Sala-i Martin, 1997: 9-10) in which it is argued that factors such as military coups, internal conflicts and wars negatively affect economic growth.

In evaluating the relationship between institutional quality and economic growth with respect to changes in institutional quality due to economic crisis, five out of twelve of the variables constructed by multiplication of institutional quality indicators with a dummy variable are statistically significant. These are Socioeconomic Conditions, Investment Profile, Religious Tensions, Democratic Accountability and Bureaucracy Quality variables. These statistically significant variables, except Religious Tensions, are positively signed. These results imply that changes in socio-economic conditions, investment profile, a level of democratic participation and bureaucratic quality due to economic crises of countries 
in the sample positively affected their economic growth rate. Notable institutional quality variables together with economic crisis are Bureaucracy Quality and Socioeconomic Conditions in which 1 unit increase due to economic crises results in $16.75 \%$ and $10.68 \%$ rise in economic growth, respectively. In addition, 1 unit increase in Investment Profile and Democratic Accountability raises economic growth 5.86\% and 5.00\%, respectively. Thus, it can be concluded that countries restructured their bureaucratic organization, made better socioeconomic and investment conditions after their economic crises and all these changes resulted in higher economic growth.

\section{Conclusion}

The literature mostly investigates the relationship between institutional quality and economic growth and there is an agreement on the positive effect of institutional quality on economic growth. This study contributes to the literature by linking economic crisis in this relationship. We assume that countries that experienced economic crisis improved their institutions and this change, in turn, has affected their economic growth positively.

In order to investigate this assumption, we employed the economic growth model of Mankiw, Romer, Weil (1992) for nine countries over the period of 1984-2010. The panel data models are estimated adding 12 institutional quality indicators to investigate the effect of institutional quality on economic growth and multiplication of these indicators with dummy variables which are proxies for economic crisis to investigate whether economic crisis contributes to economic growth of countries through changing institutional quality.

It was found that six out of twelve institutional variables of Law and Order, Religious Tensions, Military in Politics, Democratic Accountability, Internal Conflict and External Conflict positively affected economic growth. The Government Stability variable is only statistically significant but negatively signed variable. Other variables are statistically insignificant. Dummy variables with a multiplication with Socioeconomic Conditions, Investment Profile, Democratic Accountability and Bureaucracy Quality variables are statistically significant and have positive effects on economic growth. The dummy variable with a multiplication with Religious Tensions variable is the only statistically significant but negatively signed variable.

These results suggest that there is a positive relationship between institutional quality and economic growth. This conclusion is in line with the literature. In addition, economic crises change the institutional quality of countries which in turn generally positively affect the economic growth performance of countries. This study provides information for countries to consider institutions as important factors in their economic growth process and which type of institutions are more important to overcome economic crisis.

\section{References}

Acemoğlu, D. (2009). Introduction to Modern Economic Growth. New Jersey: Princeton University Press.

Acemoğlu, D., Johnson, S., and Robinson, J.A. (2005). "Institutions as a Fundamental Cause of Long-Run Growth," in P. Aghion and S. Durlauf (eds.), Handbook of Economic Growth, Amsterdam, North Holland: Elsevier. 
Acemoğlu, D., Johnson, S., Robinson, J., and Y. Thaicharoen, Y. (2003). "Institutional Causes, Macroeconomic Symptoms: Volatility, Crises and Growth," Journal of Monetary Economics, 50: $49-123$.

Alesina, A. and Weder, B. (1999). "Do Corrupt Governments Receive Less Foreign Aid?' NBER Working Paper, No. 7108.

Alesina, A. and Wagner, A. (2003). "Choosing (and reneging on) Exchange Rate Regimes," NBER Working Paper, No. 9809.

Alesina, A., Ozler, S., Roubini, N., and Swagel, P. (1996). "Political Instability and Economic Growth," Journal of Economic Growth, 1(2): 189-211.

Aron, J. (2000). "Growth and Institutions: A Review of the Evidence," The World Bank Research Observer, 15(1): 99-135.

Asteriou, D. and Price, S. (2001). "Political Instability and Economic Growth: UK Time Series Evidenc," Scottish Journal of Political Economy, 48(4): 383-399.

Baltagi, B.H. (2013): Econometric Analysis of Panel Data. UK: John Wiley \&Sons Ltd.

Barro R.J. and Sala-i-Martin, X. (1997): ‘Technological Diffusion, Convergence, and Growth,” Journal of Economic Growth, 2: 1-27.

Barro, R.J. (1996). "Determinants of Economic Growth: A Cross-Country Empirical Study,” NBER Working Paper, No. 5698.

Barro, R.J. and Lee, J.W. (2010): “A New Data Set of Educational Attainment in the World, 19502010,” NBER Working Paper, No. 15902.

Baykal, C.M. (2007). “Hukuki Boyutlarıyla Finansal Krizler,” Bankacılar Dergisi, 60(1): 33-48.

BDDK (2009). Krizden Ístikrara Türkiye Tecrübesi, Ankara: BDDK Yayınları Çalışma Tebliği.

Block, S.A. (2002). "Political Conditions and Currency Crises: Empirical Regularities in Emerging Markets," CID Working Paper, No. 79.

Brunetti, A. (1998). "Political Variables in Growth Regressions," IEA Conference Volume Series, Rrojasdatabank, http://www.rrojasdatabank.info/borner/borner6.pdf, (accessed 24 November, 2012).

Calvo, G. and Mishkin, F.S. (2003)."The Mirage of Exchange Rate Regimes for Emerging Market Countries," Journal of Economic Perspectives, 17(4): 99-118.

Dollar, D. and Kraay, A. (2003). "Institutions, Trade and Growth," Journal of Monetary Economics, 50(1): 133-162.

$\mathrm{Du}$, J. (2010). "Institutional Quality and Economic Crises: Legal Origin Theory versus Colonial Strategy Theory," The Review of Economics and Statistics, 92(1): 173-179.

Easterly, W. and Levine, R. (1997). "Africa's Growth Tragedy: Policies and Ethnic Divisions," The Quarterly Journal of Economics, 112(4): 1203-1250.

Fischer, S. (1998). 'The Asian Crises: A View from the IMF," Journal of International Financial Management and Accounting, 9(2): 167-176.

Ghosh, S.R. and Ghosh, A. (2002). "Structural Vulnerabilities and Currency Crises," IMF Working Paper, No. 02/9.

Grigorian, D.A. and Martinez, A. (2000). "Industrial Growth and the Quality of Institutions," Policy Research Working Paper, No. 2475. 
Hall, R.E. and Jones, C.I. (1999). "Why Do Some Countries Produce So Much More Output per Worker Than Others?" The Quarterly Journal of Economics, 114(1): 83-116.

Hallerberg, M. and Scartascini, C. (2011). "Economic Crisis and Fiscal Reforms in Latin America," IDB Wroking Paper, No. 235.

Helliwell, J.F. (1996). "Do Borders Matter for Social Capital? Economic Growth and Civic Culture in U.S. States and Canadian Provinces," NBER Working Paper, No. 5863.

Kennedy, P.E. (1981). "Estimation with Correctly Interpreted Dummy Variables is Semilogarithmic Equations," The American Economic Review, 71(4): 801.

Knack, S. and Keefer, P. (1995). "Institutions and Economic Performance: Cross-Country Tests Using Alternative Institutional Measures," Economics and Politics, 7(3): 207-227.

Lane, T. (1999). 'The Asian Financial Crisis What Have We Learned?" Finance \& Development, 36(3): 44-47.

Levine, R. and Renelt, D. (1992). "A Sensitivity Analysis of Cross-Country Growth Regressions," American Economic Review, 82(4): 942-963.

Mankiw, N.G., Romer, D., and Weil, D.N. (1992). "A Contribution to the Empirics of Economic Growth," Quarterly Journal of Economics, 107(2): 407-437.

Mauro, P. (1995). “Corruption and Growth,” The Quarterly Journal of Economics, 110(3): 681-712.

Montalvo, J.G. and Reynal-Querol, M. (2002). "The Effect of Ethnic and Religious Conflict on Growth," http://www.econ.upf.edu/ montalvo/sec1034/jde.pdf, (accessed 12 June 2013).

Mulder, C., Perrelli, R. and Rocha, M. (2002). "The Role of Corporate, Legal and Macroeconomic Balance Sheet Indicators in Crisis Detection and Prevention," IMF Working Paper, No. 59.

North, D.C. (1994). "Economic Performance through Time," The American Economic Review, 84(3): 359-368.

Olson, M. (1996). "Distinguished Lecture on Economics in Government: Big Bills Left on The Sidewalk: Why Some Nations are Rich, and Others Poor," Journal of Economic Perspectives, 10(2): 3-24.

Rajan, R.G. and Luigi, Z. (1998). "Which Capitalism? Lessons from the East Asian Crisis," Journal of Applied Corporate Finance, 11(3): 40-48.

Rodrik, D. (2000). "Institution for High- Quality Growth: What They are and How to Acquire Them," Studies in Comparative International Development, 35(3): 3-31.

Sala-i-Martin, X. (1997). “I Just Ran Four Million Regressions,” NBER Working Papers, No. 6252.

Shimpalee, P. and Breue, J.B. (2006). "Currency Crises and Institutions," Journal of International Money and Finance, 25(1): 125-145.

-----, (2007). “An Event Study of Institutions and Currency Crises," Review of Financial Economics, 16(3): 274-290.

Tanzi, V. and Davoodi, H. (1997). “Corruption, Public Investment and Growth,” IMF Working Paper, No. 139.

Topallı, N. (2006). "Kriz Sonrası Uygulanan IMF Tipi İstikrar Programları ve Ekonomik Etkileri: Güneydoğu Asya ve Türkiye Örneği," Selçuk Üniversitesi Karaman İktisadi ve İdari Bilimler Fakültesi Dergisi, 9(11): 143-156.

Wooldridge, J.M. (2010). Econometric Analysis of Cross Section and Panel Data. Cambridge: The MIT Press. 